\title{
EFFECT OF CHARCOAL APPLICATION ON THE EARLY GROWTH STAGE OF Acacia mangium and Michelia montana
}

\author{
Chairil Anwar Siregar
}

\begin{abstract}
Charcoal, or black coloured carbon-predominated stuff, is produced during incomplete combustion of woody plant biomass. Charcoal application to the soil can improve chemical and nutritional nature thereby inducing better plant growth and development. However, the utilization of charcoal in forestry sector, especially industrial plantation, has not been introduced due to the absence of available information. Indicator species used in this study are Acacia mangium and Michelia montana. A. mangium is one of the most important species grown in industrial plantations in Indonesia. Meanwhile M. montana is critical endemic species in Gunung Halimun National Park. Glasshouse research was designed to examine the effectiveness of charcoal incorporation into marginal soils on the growth of 6-month-old Acacia mangium and 6-month-old Michelia montana. Charcoal treatments were 0, 10,15 and $20 \%$ (v/v) for $A$. mangium, while 0, 5, 10, 15 and $20 \%(\mathrm{v} / \mathrm{v})$ for $M$. montana. Representative samples of Orthic Acrisol (i.e. Very fine, mixed, semiactive, isohyperthermic, and Typic Paleudult) were collected from $\mathrm{B}$ horizon. A completely randomized design with four replications (for $A$. mangium) and five replications (for $M$. montana) was employed to examine the effect of charcoal application on the plant growth and some important chemical properties of the corresponding soil. Charcoal additions to the soil significantly increased height, diameter, and leaf and stem biomass weight of A. mangium, and significantly increased height, diameter, and total biomass weight of $M$. montana seedlings in comparison to those of a control. Increasing the amount of charcoal higher than $10 \%$ level, however, have little effect on $A$. mangium growth. On the other hand, increasing the amount of charcoal higher than $10 \%$ is still effective on $M$. montana growth. This study indicated that charcoal application at the rates of $10 \%$ for $A$. mangium and $15 \%$ for $M$. montana would be adequate to improve the availability of soil nutrients, and hence significantly induce a better plant growth response.
\end{abstract}

Keywords: Charcoal application, soil nutrients, Acacia mangium, Michelia montana

\section{INTRODUCTION}

Two primary processes are relevant to carbon sequestration including carbon dioxide uptake through photosynthesis and longevity of assimilated carbon. As carbon dioxide gas in the atmosphere is absorbed by plants and converted into carbohydrates in the photosynthesis process (in the presence of chlorophyll and solar radiation), forest vegetations are becoming especially important in the global carbon cycle due to the fact that they are affecting the ecosystems with the greatest biomass and hold the largest carbon pool. Holdgate (1995) reviewed that in a given live vegetation, forest contained 400-550 billions tons of carbon, holding approximately ten times as much carbon as any other major vegetations.

\footnotetext{
${ }^{1}$ Forest and Nature Conservation Research and Development Center, Bogor
} 
Effectiveness of organic or biomass production from natural forests and plantation forests are well understood as a potential carbon sink. However, the fixation and storage of carbon for longer period of time still endure some constraints such as forest fire accident and high wood consumption in village and industry sector. As a result, managing forest plantation to enhance both wood production and carbon stock requires a formulation of applicable method wherein the activity of organic carbon mass-produced is suppressed and whenever possible used as such to improve site quality of plantation forests. By the same token, organic carbon storage and soil carbon sequestration processes employed to furnish better growing condition are simultaneously established.

Land preparation prior to forest planting and forest harvest activities always generate forest waste composed of leaves and twigs. It also includes inferior and nonharvestable trees. Some amount of this forest waste traditionally is an important energy source alternative namely as fuel wood or woody waste converted charcoal. Most carbon will be released to the atmosphere when organic materials are burned as a fuel wood; in contrast, most carbon will be stored in a form of charcoal if the same organic materials undergo controlled partial combustion (pyrolysis).

In Japan, charcoal is sometimes utilized as a soil conditioner to accelerate growth of plants (Ogawa, 1994; Kishimoto, 1984). Researchers have reported the increase in plant growth, higher nutrient retention, and nutrient availability after charcoal additions to soil, and this related to higher exchange capacity, surface area, and direct nutrient additions (Glaser et. al., 2002). In addition, charcoal was reported to be responsible for high organic matter contents in the soil and the fertility of anthropogenic soils found in central Amazonia. In contrast, charcoal application at high rate may produce detrimental effects on crop growth (Kishimoto and Sugiura, 1985; Siregar, 2002).

Owing to the fact that the formation of charcoal during incomplete burning (slash and burn) would lead to the long term sequestering of carbon in soils and sediments and therefore provide a sink for atmospheric carbon (Fearnside, 1991), this preliminary research hence, is designed at examining soil amendment through charcoal application with the potential to enhance better plant growth and soil carbon sequestration. This research, then, would evaluate the plant growth response to promote the most judicious use of charcoal in the plantation of $A$. mangium and $M$. montana.

\section{MATERIAL AND METHODS}

\section{A. Preparation of Soil and Charcoal}

Representative samples of Orthic Acrisol (Very fine, mixed, semiactive, isohyperthermic, and Typic Paleudult) and Dystric Nitosol (Fine, mixed, active, isohyperthermic Typic Hapludult) were collected from B horizons (50-75 cm deep) located at Maribaya and Cianten in the KPH (Forestry District) Bogor, Perum Perhutani Unit III, West Java. These soils were used to grow $A$. mangium and $M$. Montana respectively.

Soil samples were ground and thoroughly mixed before potting (polybag). From the soil samples, $4000 \mathrm{~g}$ (air dry) were weighed into individual pots. A completely randomized design with four replications was employed to examine the seedling growth as affected by 
charcoal application. Levels of crushed charcoal applications were $0 \%, 10 \%, 15 \%$, and $20 \%$ $(\mathrm{v} / \mathrm{v})$ in the case of $A$. mangium seedlings. One experimental unit was five potted seedlings. Meanwhile in the case of $M$. montana seedlings, levels of crushed charcoal applications were $0 \%, 5 \%, 10 \%, 15 \%$, and $20 \%$. Five replications was employed to examine the effect of charcoal application on the M. montana growth and some important chemical properties of the soil. The charcoal was ground to pass a $5 \mathrm{~mm}$ sieve and thoroughly mixed with the soils before potting. The levels of charcoal applications were prepared by mixing together charcoals in particular amount and soils that further provided each of the charcoal concentration. No inorganic fertilizer was used in this experiment. Soil moisture was brought to field capacity at the beginning of the study and every three days thereafter for 6 months.

At the beginning and the end of the study period, soil samples from each pot were collected, air dried, passed through $2 \mathrm{~mm}$ sieve, and stored for chemical analyses.

\section{B. Plant Height, Diameter and Biomass Measurement}

A. mangium seedlings were replanted in June 10, 2003 and were harvested December 4, 2003. Plant height and diameter at ground level were recorded from five seedlings in each experimental unit every two- months. M. montana seedlings were replanted in April 22, 2004 and were harvested November 2, 2004. Initial plant height data were also collected at the first week after replanting. At harvesting time, total plant biomass was separated from soils and after wards top root ratio and total biomass weight were recorded.

\section{Statistical Analysis}

In this study, evaluation of treatment differences were conducted by analysis of variance using Statistical Analysis System (SAS Institute, 1998). Unless otherwise indicated, significance is indicated at $\mathrm{P} \leq 0.05$. Further mean separation test, if necessary, was conducted by employing LSD test procedure.

\section{RESULTS AND DISCUSSION}

\section{A. Acaciamangium}

\section{Plant Growth with Charcoal Application}

Some important chemical properties of charcoal are presented in Table 1, meanwhile some important soils chemical properties at replanting time (1 week after charcoal was added to the soils) are given in Table 2.

Charcoal application significantly influenced plant height at the ages of 2, 4 and 6 months, plant diameter, leaf dry weight, stem dry weight, top root ratio, and $\mathrm{C} / \mathrm{F}$ $[($ root + stem)/leaf $]$ at the age of 6 months (Table 3). Charcoal application had no effect on root dry weight. It is essential to note that optimum plant height was produced at $10 \%$ charcoal application at all ages (Table 4). It is also interesting to note that in most cases, 
charcoal application at $10 \%$ level gave better results in terms of leaf and stem dry weight, top root ratio and C/F [(root+stem)/leaf] as compared to control and the other levels of charcoal application.

Root dry weight was essentially constant across charcoal application. One explanation for this may be due to good soil-rhizosphere circumstance already presented even without charcoal addition to the soils. In other words, sufficient soil nutrient level to support root growth was there. As stem and leaf dry weight increased significantly at $10 \%$ charcoal application and meanwhile the root dry weight remained constant, consequently this resulted in the improvement of top to root ratio parameter.

Soil nutrient status is one important growth factor that affects assimilation ability, which is a critical determinant for growth of plant and survival of seedlings. In addition to assimilation, respiration is a critical determinant of net carbon gain (net primary production) in seedlings at the whole plant level.

Table 1. Some important chemical properties of charcoal

\begin{tabular}{|c|c|}
\hline $\mathrm{pH}\left(\mathrm{H}_{2} \mathrm{O}\right)$ & 8 \\
\hline $\mathrm{pH}(\mathrm{KCl})$ & 8 \\
\hline $\mathrm{C}$ - Organic, $\%$ & 55 \\
\hline $\mathrm{N}$ - Kjeldahl, \% & 0.1 \\
\hline $\mathrm{C} / \mathrm{N}$ & 131 \\
\hline P Potential $\left(\mathrm{HCl} 25 \%, \mathrm{P}_{2} \mathrm{O}_{5}\right), \mathrm{ppm}$ & 290.6 \\
\hline K Potential $\left(\mathrm{HCl} 25 \%, \mathrm{~K}_{2} \mathrm{O}\right), \mathrm{mg} / 100 \mathrm{~g}$ & 18 \\
\hline $\mathrm{P}$ - available $\left(\right.$ Bray, $\left.\mathrm{P}_{2} \mathrm{O}_{5}\right), \mathrm{ppm}$ & 69 \\
\hline $\mathrm{K}$ - available (Morgan, $\mathrm{K}_{2} \mathrm{O}$ ), ppm & 133 \\
\hline $\mathrm{Ca}$ (1 N NH4Oac, pH 7.0 extraction), me/100 g & 28 \\
\hline Mg (1 N NH4Oac, pH 7.0 extraction), me/ $100 \mathrm{~g}$ & 8 \\
\hline $\mathrm{K}$ (1 N NH4Oac, pH 7.0 extraction), me/100 g & 17 \\
\hline $\mathrm{Na}$ (1 N NH4Oac, pH 7.0 extraction), me/100 g & 2 \\
\hline Total (1 N NH4Oac, pH 7.0 extraction), me/100 g & 55 \\
\hline CEC (1 N NH4Oac, pH 7.0 extraction), me/100 g & 19 \\
\hline $\mathrm{BS}, \%$ & $>100$ \\
\hline $\mathrm{KCl} 1 \mathrm{~N}, \mathrm{Al}^{3+}, \mathrm{me} / 100 \mathrm{~g}$ & 0 \\
\hline $\mathrm{KCl} 1 \mathrm{~N}, \mathrm{H}^{+}, \mathrm{me} / 100 \mathrm{~g}$ & 0 \\
\hline
\end{tabular}


Table 2. Some important soil chemical properties at replanting time of $A$. mangium

\begin{tabular}{|c|c|c|c|c|c|c|c|c|c|}
\hline \multirow[t]{2}{*}{$\begin{array}{l}\text { Treat - } \\
\text { ment }\end{array}$} & $\begin{array}{c}\mathrm{pH} \\
\left(\mathrm{H}_{2} \mathrm{O}\right)\end{array}$ & $\begin{array}{c}\mathrm{pH} \\
(\mathrm{KCl})\end{array}$ & $\begin{array}{c}\mathrm{C}- \\
\text { Orga- } \\
\text { nic }\end{array}$ & $\begin{array}{c}\text { N- } \\
\text { Kjel - } \\
\text { dahl }\end{array}$ & \multirow[t]{2}{*}{$\mathrm{C} / \mathrm{N}$} & $\begin{array}{l}\text { P Poten- } \\
\text { tial (HCl } \\
25 \% \\
\left.\mathrm{P}_{2} \mathrm{O}_{5}\right) \\
\end{array}$ & $\begin{array}{c}\text { K Poten- } \\
\text { tial }(\mathrm{HCl} \\
25 \% \\
\left.\mathrm{~K}_{2} \mathrm{O}\right) \\
\end{array}$ & $\begin{array}{c}\mathbf{P}- \\
\text { available } \\
(\mathrm{Bray}, \\
\left.\mathrm{P}_{2} \mathrm{O}_{5}\right) \\
\end{array}$ & $\begin{array}{c}\mathbf{K}- \\
\text { available } \\
\text { (Morgan, } \\
\left.\mathbf{K}_{2} \mathbf{O}\right) \\
\end{array}$ \\
\hline & & & \multicolumn{2}{|c|}{$\%$} & & \multicolumn{2}{|c|}{$\mathrm{mg} / 100 \mathrm{~g}$} & \multicolumn{2}{|c|}{$\mathrm{ppm}$} \\
\hline $\mathrm{A}-0 \%$ & 4.4 & 3.7 & 0.61 & 0.12 & 5 & 13 & 51 & 3.0 & 29.5 \\
\hline B-10\% & 4.5 & 3.9 & 1.04 & 0.19 & 5 & 20 & 45 & 4.8 & 340.8 \\
\hline C-15\% & 4.6 & 4.0 & 1.40 & 0.18 & 8 & 20 & 67 & 8.0 & 510.9 \\
\hline D-20\% & 4.8 & 4.0 & 1.45 & 0.23 & 6 & 25 & 105 & 22.3 & 746.8 \\
\hline \multirow{3}{*}{$\begin{array}{l}\text { Treat - } \\
\text { ment }\end{array}$} & \multicolumn{6}{|c|}{$\begin{array}{c}1 \mathrm{~N} \mathrm{NH} 4 \mathrm{Oac}, \mathrm{pH} 7.0 \text { extraction } \\
\text { Exchangeable bases }\end{array}$} & \multirow[t]{2}{*}{ BS } & $\begin{array}{c}\mathrm{KCl} 1 \\
\mathrm{~N} \cdot \mathrm{Al}^{3+}\end{array}$ & \multirow[t]{2}{*}{$\begin{array}{c}\mathrm{KCl} 1 \mathrm{~N} \\
\mathrm{H}^{+}\end{array}$} \\
\hline & $\mathrm{Ca}$ & $\mathrm{Mg}$ & $\mathbf{K}$ & $\mathrm{Na}$ & Total & CEC & & & \\
\hline & \multicolumn{5}{|c|}{$\mathrm{Me} / 100 \mathrm{~g}$} & & $\%$ & \multicolumn{2}{|c|}{$\mathrm{me} / 100 \mathrm{~g}$} \\
\hline A- $0 \%$ & 0.25 & 0.85 & 0.06 & 0.13 & 1.29 & 34.83 & 4 & 19.17 & 0.95 \\
\hline B-10\% & 1.75 & 1.19 & 0.72 & 0.17 & 3.83 & 33.91 & 11 & 15.93 & 0.46 \\
\hline C-15\% & 2.24 & 1.25 & 1.08 & 0.17 & 4.74 & 29.27 & 16 & 13.82 & 0.36 \\
\hline D-20\% & 3.21 & 1.44 & 1.58 & 0.16 & 6.39 & 29.53 & 22 & 9.07 & 0.44 \\
\hline
\end{tabular}

$\mathrm{A}, \mathrm{B}, \mathrm{C}$, and $\mathrm{D}$ refer to charcoal application level, i.e. Consecutively $0 \%, 10 \%, 15 \%$, and $20 \%$

Table 3. Summary of analysis of variance for plant growth variable as affected by charcoal application at the ages of 2, 4 and 6 months

\begin{tabular}{cccccccc}
\hline & \multicolumn{6}{c}{ Variable } \\
\cline { 2 - 6 } Treatment & Height & $\begin{array}{c}\text { Diame- } \\
\text { ter }\end{array}$ & $\begin{array}{c}\text { Leaf dry } \\
\text { weight }\end{array}$ & $\begin{array}{c}\text { Stem } \\
\text { dry } \\
\text { weight }\end{array}$ & $\begin{array}{c}\text { Root dry } \\
\text { weight }\end{array}$ & $\begin{array}{c}\text { Top root } \\
\text { ratio }\end{array}$ & $\mathrm{C} / \mathrm{F}$ \\
\hline
\end{tabular}

Two months

Charcoal 1)

Four months

Charcoal 1)

Six months

\begin{aligned} Charcoal 1) & $* * \quad * * \quad * * \\$\hline Notes : - & $=$ no observation \\ $* & =$ significant at the $5 \%$ level \\ $* * & =$ significant at $1 \%$ level \\ $\mathrm{ns} & =$ not significant \\ $\mathrm{C} / \mathrm{F} & =$ (root + stem) $/$ leaf \\ $1) & =$ With the application level varied about $0-20 \%\end{aligned}$


Table 4. Effect of charcoal application on the plant growth variable at the ages of 2, 4 and 6 months

\begin{tabular}{|c|c|c|c|c|c|c|c|}
\hline \multirow{2}{*}{$\begin{array}{c}\text { Charcoal } \\
\text { application } \\
\% \\
\end{array}$} & \multicolumn{7}{|c|}{ Variable } \\
\hline & $\begin{array}{c}\mathrm{H} \\
(\mathrm{cm})\end{array}$ & $\begin{array}{c}\mathrm{D} \\
(\mathrm{cm})\end{array}$ & $\begin{array}{l}\text { LDW } \\
\text { (gram) }\end{array}$ & $\begin{array}{l}\text { SDW } \\
\text { (gram) }\end{array}$ & $\begin{array}{l}\text { RDW } \\
\text { (gram) }\end{array}$ & $\mathbf{T} / \mathbf{R}$ & $\mathrm{C} / \mathrm{F}$ \\
\hline & \multicolumn{7}{|c|}{2 months } \\
\hline 0 & $5.4 \mathrm{~B}$ & - & - & - & - & - & - \\
\hline 10 & $7.1 \mathrm{~A}$ & - & - & - & - & - & - \\
\hline 15 & $6.5 \mathrm{~A}$ & - & - & - & - & - & - \\
\hline \multirow[t]{2}{*}{20} & $6.8 \mathrm{~A}$ & - & - & - & - & - & - \\
\hline & \multicolumn{7}{|c|}{4 months } \\
\hline 0 & $9.3 \mathrm{~B}$ & - & - & - & - & - & - \\
\hline 10 & $15.0 \mathrm{~A}$ & - & - & - & - & - & - \\
\hline 15 & $14.2 \mathrm{~A}$ & - & - & - & - & - & - \\
\hline \multirow[t]{2}{*}{20} & $14.6 \mathrm{~A}$ & - & - & - & - & - & - \\
\hline & \multicolumn{7}{|c|}{6 months } \\
\hline 0 & $12.8 \mathrm{~B}$ & $1.6 \mathrm{~B}$ & $0.1 \mathrm{~B}$ & $0.4 \mathrm{~B}$ & $0.4 \mathrm{a}$ & $2.7 \mathrm{~B}$ & $1.4 \mathrm{~A}$ \\
\hline 10 & $23.4 \mathrm{~A}$ & $2.4 \mathrm{~A}$ & $1.5 \mathrm{~A}$ & $0.8 \mathrm{~A}$ & $0.6 \mathrm{a}$ & $4.4 \mathrm{~A}$ & $1.0 \mathrm{~B}$ \\
\hline 15 & $23.0 \mathrm{~A}$ & $2.4 \mathrm{~A}$ & $1.6 \mathrm{~A}$ & $0.8 \mathrm{~A}$ & $0.5 \mathrm{a}$ & $4.3 \mathrm{~A}$ & $0.9 \mathrm{~B}$ \\
\hline 20 & $23.5 \mathrm{~A}$ & $2.4 \mathrm{~A}$ & $1.6 \mathrm{~A}$ & $0.7 \mathrm{AB}$ & $0.5 \mathrm{a}$ & $4.5 \mathrm{~A}$ & $0.8 \mathrm{~B}$ \\
\hline
\end{tabular}

Note: Values followed by different letters within a column are significantly different - = no observation; $\mathrm{H}=$ height; $\mathrm{D}=$ diameter; $\mathrm{LDW}=$ leaf dry weight; $\mathrm{SDW}=$ stem dry weight; RDW = root dry weight; $\mathrm{T} / \mathrm{R}=$ top to root ratio; $\mathrm{C} / \mathrm{F}=($ root+stem $)$ /leaf ratio

Several components in plant part / tissues (leaf, stem, and root) accumulate, store and retranslocate different amounts of nutrients and hence influence the dynamic relation between nutrients, tissue production, and rates of photosynthesis. Since the respiration rate of leaf is generally higher than that of supporting tissues such as stem and roots, Ishida et al. (2000) pointed that dry matter partitioned among plant parts is important for the daily carbon gain of whole plants. This growth parameter is a prerequisite to reach a better understanding of plant growth and development progress over time.

Observations of data in Table 4 suggest that top root ratio (T/R) as high as 4.4 and $\mathrm{C} / \mathrm{F}$ as high as 1.0 coincides with the significant increase of other growth parameters (plant height and diameter, stem dry weight and leaf dry weight) as affected by $10 \%$ charcoal application. Moreover, based on the physical appearance of the $A$. mangium plant, it is apparent that $\mathrm{T} / \mathrm{R}$ that ranges from 4.3 to 4.5 is classified as satisfaction when compared to that of 2.7, which received no charcoal application. Likewise, $\mathrm{C} / \mathrm{F}$ value of 1.0 is attributed to better plant growth as compared to higher $\mathrm{C} / \mathrm{F}$ value of 1.4 attributed to poor plant growth.

Results obtained from this experiment mostly are consistent with observations reported by some researchers. Chidumayo (1994) reported generally better seed germination (30\% increase), shoot heights $(24 \%)$, and biomass production $(13 \%)$ of woody plant growing on Alfisols and Ultisols under kiln charcoal. Working with sugi trees (Cryptomeria japonica) on clay loam soils, five years after charcoal application at the rate of $0.5 \mathrm{Mg} \mathrm{ha}^{-1}$, Kishimoto and Sugiura (1985) found out that the heights of sugi trees increased by a factor of $1.26-1.35$ and the biomass production increased by a factor of $2.31-2.36$. Ishii and Kadoya 
(1994) also reported that the fresh weights of the root, shoot and the whole mandarin tree one year after replanting, increased in response to charcoal application at the rate of $2 \%$ $(\mathrm{w} / \mathrm{w})$. Unlike those reported, root dry weight observed in this experiment was not significantly affected by the charcoal application. Speculation for the lack of root growth response to this charcoal addition was due to the sufficient soil fertility level (at this growth stage) as indicated by relatively high soil CEC value (approx. $30 \mathrm{me} / 100 \mathrm{gr}$ ) but with very low percentage of BS (approx. $4-6 \%$ ).

\section{Soil pH, Nutrient Availability, and Retention}

Charcoal application significantly influenced soil $\mathrm{pH}, \mathrm{C}$ organic, $\mathrm{N}, \mathrm{P}, \mathrm{K}, \mathrm{C} / \mathrm{N}$, exchangeable bases, CEC, BS, Al, and $\mathrm{H}$ (Table 5). Generally, soil variables at harvesting time increased with the increase of charcoal application, except Bray's extractable $\mathrm{P}$, and $\mathrm{Na}$, which are fluctuating, $\mathrm{CEC}, \mathrm{Al}$ and $\mathrm{H} \sim 10 \mathrm{pH}$, which are decreasing (Table 6).

Table 5. Summary of analysis of variance for soil properties as affected by charcoal treatment

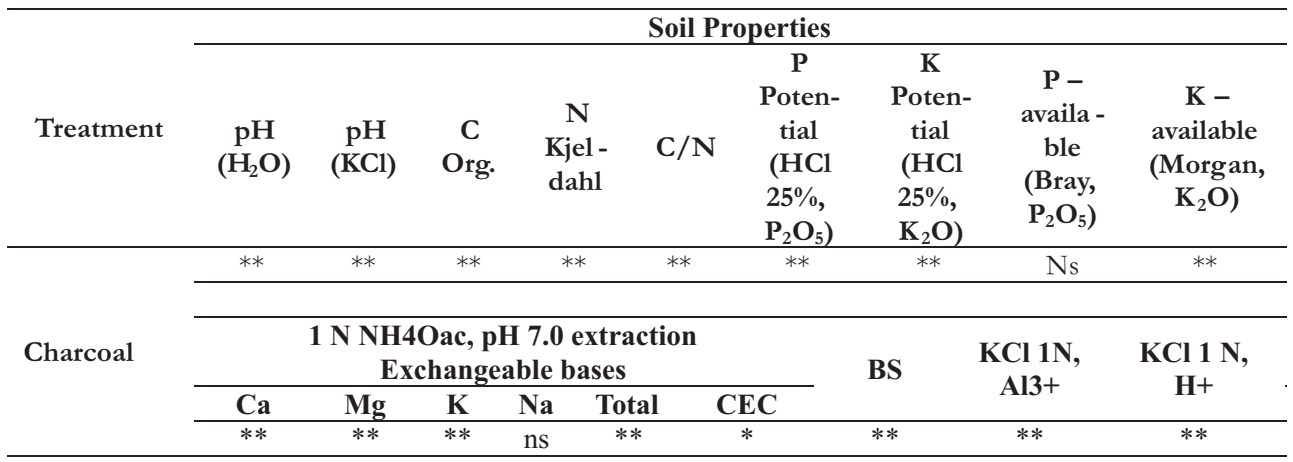

Notes : $*$ significant at $5 \%$ level

$* *=$ significant at $1 \%$ level

ns $=$ not significant

Soil $\mathrm{pH}$ changes as affected by charcoal application were observed. The soil reaction increased gradually with the increase in charcoal application. Charcoal addition to the soils functioned like liming effect phenomenon as basic cations originated from charcoal ashes can neutralize the soil acidity. Note that soil $\mathrm{pH}$ is higher by $0.4-0.6$ unit due to charcoal addition as compared to that of control. Application of charcoal that can increase the soil $\mathrm{pH}$, and decrease $\mathrm{Al}$ saturation and $\mathrm{H}$ is well documented, and is often used to improve the fertility of highly weathered tropical soils (Sanchez et. al., 1983).

The present of basic cations originated from charcoal ashes on the ligand exchange gave rise to the reduction in acidic cations and the increased in basic cations, and in turn, resulted in an increase in soil $\mathrm{pH}$ (Foth, 1990). This experiment indicated that exchangeable bases $(\mathrm{Ca}, \mathrm{Mg}, \mathrm{K}$, and $\mathrm{Na}$ ) mostly increased with the increase in charcoal application. Consequently, the base saturation also increased and was becoming three to four fold higher after charcoal application. 
Charcoal addition to soil at the rate up to $20 \%$ also increased organic $\mathrm{C}$ and total N. The trend of organic $\mathrm{C}$ and total $\mathrm{N}$ increased as the rate of charcoal application increased was also reported by Glaser et. al (2002). Equally, potential P considerably increased as charcoal was added to the soils at the rate of $10 \%$. These data are apparent since charcoal contains some amounts of elemental C, N, P, and others (Table 1). Eventhough available soil $\mathrm{P}$ did not significantly increase as the rate of charcoal application increased, the elevated trend was observed, and was consistent with the trend noticed at replanting time. Note that the available P occurred at charcoal application at the rate of $15 \%$ was lower than that of $10 \%$, and this unexpected result appears to be due to random variation rather than charcoal addition.

Table 6. Effect of charcoal application on soil properties at harvesting time

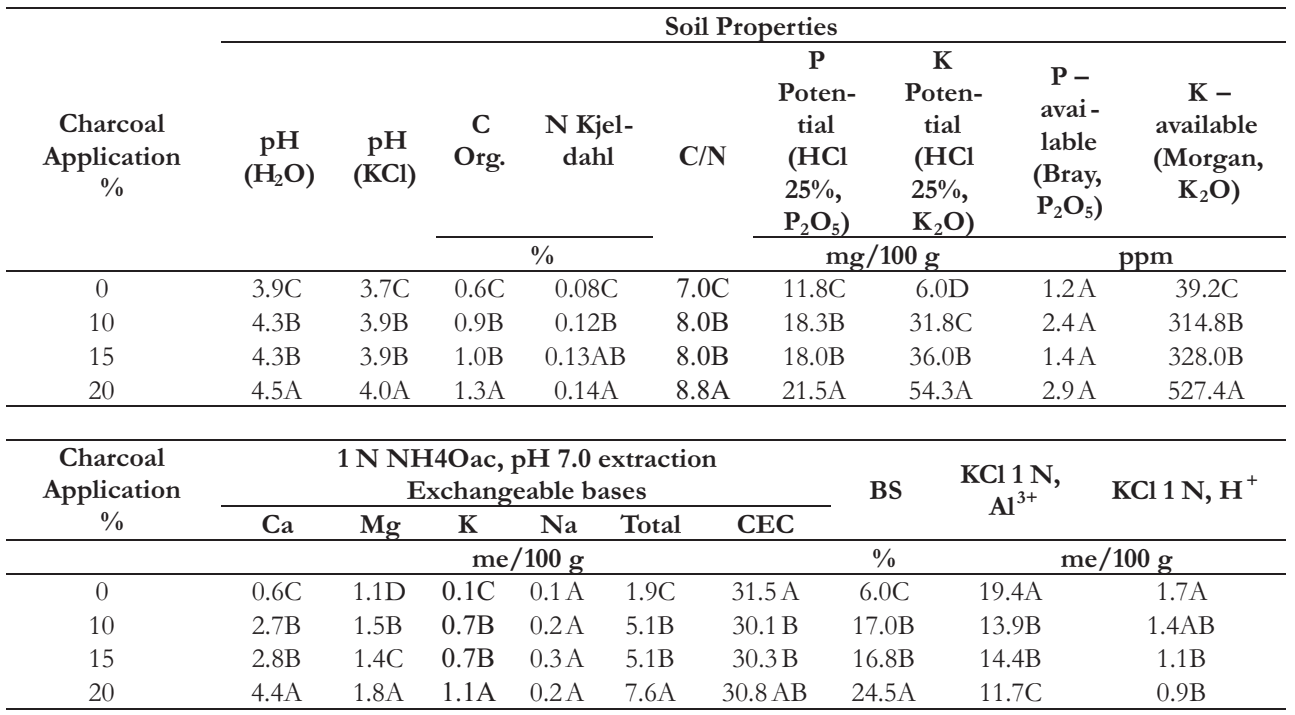

Note: Values followed by different letters within a column are significantly different

Soil CEC level significantly decreased as the rate of charcoal application increased. However, most researchers have observed that soil CEC tends to increase following charcoal addition to the soils (Glaser et. al., 2002). They assumed that slow oxidation on the edges of the aromatic backbone of charcoal forming carboxylic groups is responsible for both the potential of forming organo-mineral complexes and the sustainably increased CEC. It is also documented that hardwood charcoal increased the CEC compared to that of the original soils, meanwhile conifer charcoal decreased the CEC. The latter case should be wisely observed bearing in mind that the charcoal CEC (19 me/100 gr) used in this experiment is much lower than that of the soils $(30 \mathrm{me} / 100 \mathrm{gr})$. 


\section{B. Michelia montana}

\section{Plant Growth with Charcoal Application}

Charcoal application significantly affected plant height, diameter, number of leaves, leaf dry weight, root dry weight, stem dry weight, and total dry weight at the age of 6 months (Table 7). Note that the magnitude of all parameters observed increased as the level of charcoal applications increased except $\mathrm{C} / \mathrm{F}$, and this growth response appears to be almost in linear fashion in most cases. At this growing stage, the maximum plant height, diameter, number of leaves, and total dry weight were obtained at $20 \%$ charcoal application (Table 8). The trend of $\mathrm{C} / \mathrm{F}$ is inversely correlated with the trend of $\mathrm{T} / \mathrm{R}$. The $\mathrm{C} / \mathrm{F}$ as high as 1.21 (the lowest) seems to be the most vigor plant performance and this coincides with the highest magnitude of $\mathrm{T} / \mathrm{R}$. In contrast to the case of $A$. mangium, it is remarkable to observe that the plant growth responses possibly keep increasing, as dosage of charcoal application is greater than $20 \%$. This result suggests that $A$. mangium and $M$. montana gave different growth response from one another as some particular amount of charcoal is added to the soils.

Table 7. Summary of analysis of variance for $M$. montana growth variable as affected by charcoal application at the age of 6 months

\begin{tabular}{|c|c|c|c|c|c|c|c|c|c|}
\hline \multirow{2}{*}{ Treatment } & \multicolumn{9}{|c|}{ Variable } \\
\hline & $\mathrm{H}$ & D & NL & LDW & SDW & RDW & TDW & $T / R$ & $\mathrm{C} / \mathrm{F}$ \\
\hline Charcoal & ** & ** & ** & ** & ** & ** & ** & ** & ** \\
\hline
\end{tabular}

Table 8. Effect of charcoal application on M. montana growth variable at the age of 6 months

\begin{tabular}{cccccccccc}
\hline \multirow{2}{*}{$\begin{array}{c}\text { Charcoal } \\
\text { application \% }\end{array}$} & \multicolumn{10}{c}{ V } & D & NL & LDW & SDW & RDW & TDW & T/R & C/F \\
\hline 0 & $39.0 \mathrm{C}$ & $2.0 \mathrm{C}$ & $14 \mathrm{~B}$ & $0.08 \mathrm{D}$ & $0.07 \mathrm{C}$ & $0.09 \mathrm{C}$ & $0.23 \mathrm{C}$ & $1.68 \mathrm{~B}$ & $\mathbf{2 . 0 2 A}$ \\
5 & $41.4 \mathrm{C}$ & $2.6 \mathrm{BC}$ & $13 \mathrm{~B}$ & $0.24 \mathrm{C}$ & $0.14 \mathrm{BC}$ & $0.24 \mathrm{~B}$ & $0.61 \mathrm{~B}$ & $1.59 \mathrm{~B}$ & $1.54 \mathrm{~B}$ \\
10 & $43.5 \mathrm{C}$ & $2.6 \mathrm{BC}$ & $14 \mathrm{~B}$ & $0.29 \mathrm{BC}$ & $0.16 \mathrm{~B}$ & $0.27 \mathrm{~B}$ & $0.71 \mathrm{~B}$ & $1.69 \mathrm{~B}$ & $1.46 \mathrm{~B}$ \\
15 & $57.2 \mathrm{~B}$ & $2.8 \mathrm{~B}$ & $14 \mathrm{~B}$ & $0.41 \mathrm{~B}$ & $0.21 \mathrm{~B}$ & $0.34 \mathrm{~B}$ & $0.97 \mathrm{~B}$ & $1.84 \mathrm{AB}$ & $1.35 \mathrm{~B}$ \\
$\mathbf{2 0}$ & $\mathbf{8 5 . 2 \mathrm { A }}$ & $\mathbf{4 . 2} \mathrm{A}$ & $\mathbf{1 7} \mathrm{A}$ & $\mathbf{1 . 0 0 A}$ & $\mathbf{0 . 5 2 A}$ & $\mathbf{0 . 7 0 A}$ & $\mathbf{2 . 2 1 A}$ & $\mathbf{2 . 1 8 A}$ & $1.21 \mathrm{~B}$ \\
\hline
\end{tabular}

Note: Values followed by different letters within a column are significantly different

$\mathrm{H}=$ height; $\mathrm{D}=$ diameter; $\mathrm{NL}=$ Number of leaves; LDW = leaf dry weight; SDW = stem dry weight; RDW = root dry weight; TDW= total dry weight; $\mathrm{T} / \mathrm{R}=$ top to root ratio; $\mathrm{C} / \mathrm{F}=($ root + stem $) /$ leaf 


\section{Soil $\mathrm{pH}$, Nutrient Availability and Retention}

Some important chemical properties of charcoal are presented in Table 9, meanwhile some important soils chemical properties at replanting time (1 week after charcoal was added to the soils) are given in Table 10.

Charcoal application apparently influenced soil $\mathrm{pH}, \mathrm{C}$ organic, $\mathrm{N}, \mathrm{P}, \mathrm{K}$, exchangeable bases, $\mathrm{BS}, \mathrm{Al}$, and $\mathrm{H}$, but did not affect $\mathrm{CEC}$ and $\mathrm{C} / \mathrm{N}$, which were relatively constant (Table 10). In general, most of soil variables at replanting time increased with the increase of charcoal application except for $\mathrm{Al}$ and $\mathrm{H}$, which were decreased. The decrease in $\mathrm{Al}$ and $\mathrm{H}$ is obvious since the soil $\mathrm{pH}$ increases due to alkaline nature of charcoal material.

Table 9. Some important chemical properties of charcoal

\begin{tabular}{|c|c|}
\hline $\mathrm{pH}\left(\mathrm{H}_{2} \mathrm{O}\right)$ & 8.0 \\
\hline $\mathrm{pH}(\mathrm{KCl})$ & 7.8 \\
\hline C - Organic, $\%$ & 3.45 \\
\hline $\mathrm{N}$ - Kjeldahl, \% & 0.45 \\
\hline $\mathrm{C} / \mathrm{N}$ & 8 \\
\hline P Potential $\left(\mathrm{HCl} 25 \%, \mathrm{P}_{2} \mathrm{O}_{5}\right), \mathrm{ppm}$ & 111 \\
\hline K Potential $\left(\mathrm{HCl} 25 \%, \mathrm{~K}_{2} \mathrm{O}\right), \mathrm{mg} / 100 \mathrm{~g}$ & 491 \\
\hline $\mathrm{P}$ - available $\left(\mathrm{Bray}, \mathrm{P}_{2} \mathrm{O}_{5}\right), \mathrm{ppm}$ & - \\
\hline $\mathrm{K}$ - available (Morgan, $\mathrm{K}_{2} \mathrm{O}$ ), ppm & 2718.4 \\
\hline Ca (1 N NH4Oac, pH 7.0 extraction), me/100 g & 27.81 \\
\hline $\mathrm{Mg}$ (1 N NH4Oac, pH 7.0 extraction), me/100 g & 1.93 \\
\hline $\mathrm{K}$ (1 N NH4Oac, pH 7.0 extraction), me/100 g & 5.39 \\
\hline $\mathrm{Na}$ (1 N NH4Oac, pH 7.0 extraction), me/100 g & 0.84 \\
\hline Total (1 N NH4Oac, pH 7.0 extraction), me/100 g & 35.97 \\
\hline CEC (1 N NH4Oac, pH 7.0 extraction), me/100 g & 5.79 \\
\hline BS, $\%$ & $>100$ \\
\hline $\mathrm{KCl} 1 \mathrm{~N}, \mathrm{Al}^{3+}, \mathrm{me} / 100 \mathrm{~g}$ & 0.00 \\
\hline $\mathrm{KCl} 1 \mathrm{~N}, \mathrm{H}^{+}, \mathrm{me} / 100 \mathrm{~g}$ & 0.01 \\
\hline
\end{tabular}

Remark: - no analysis 
Table 10. Some important soil chemical properties at replanting time of M. montana

\begin{tabular}{|c|c|c|c|c|c|c|c|c|c|}
\hline \multirow[t]{2}{*}{$\begin{array}{l}\text { Treat - } \\
\text { ment }\end{array}$} & $\begin{array}{c}\mathrm{pH} \\
\left(\mathrm{H}_{2} \mathrm{O}\right)\end{array}$ & $\underset{(\mathrm{KCl})}{\mathrm{pH}}$ & $\begin{array}{c}\mathrm{C}- \\
\text { Orga- } \\
\text { nic }\end{array}$ & $\begin{array}{c}\text { N- } \\
\text { Kjel - } \\
\text { dahl }\end{array}$ & \multirow[t]{2}{*}{$\mathrm{C} / \mathrm{N}$} & $\begin{array}{c}\text { P Poten- } \\
\text { tial }(\mathrm{HCl} \\
25 \% \\
\left.\mathbf{P}_{2} \mathrm{O}_{5}\right)\end{array}$ & $\begin{array}{c}\text { K Poten- } \\
\text { tial }(\mathrm{HCl} \\
25 \% \\
\left.\mathrm{~K}_{2} \mathrm{O}\right)\end{array}$ & $\begin{array}{c}\mathrm{P}- \\
\text { available } \\
(\mathrm{Bray} \\
\left.\mathrm{P}_{2} \mathrm{O}_{5}\right) \\
\end{array}$ & $\begin{array}{c}\mathbf{K}- \\
\text { available } \\
\text { (Morgan, } \\
\left.\mathbf{K}_{2} \mathbf{O}\right) \\
\end{array}$ \\
\hline & & & \multicolumn{2}{|c|}{$\%$} & & \multicolumn{2}{|c|}{$\mathrm{mg} / 100 \mathrm{~g}$} & \multicolumn{2}{|c|}{ ppm } \\
\hline $\mathrm{A}-0 \%$ & 4.6 & 3.8 & 1.14 & 0.14 & 8 & 23 & 8 & 2.7 & 36.5 \\
\hline B- $5 \%$ & 4.5 & 4.0 & 1.27 & 0.16 & 8 & 31 & 32 & 5.0 & 212.4 \\
\hline C- $10 \%$ & 5.0 & 4.3 & 1.27 & 0.16 & 8 & 33 & 50 & 6.6 & 376.2 \\
\hline D-15\% & 5.4 & 4.8 & 1.46 & 0.18 & 8 & 36 & 68 & 6.7 & 542.6 \\
\hline $\mathrm{E}-20 \%$ & 6.2 & 5.6 & 1.49 & 0.19 & 8 & 43 & 100 & - & 712.4 \\
\hline \multirow{3}{*}{$\begin{array}{c}\text { Treat - } \\
\text { ment }\end{array}$} & \multicolumn{6}{|c|}{$\begin{array}{c}1 \mathrm{~N} \mathrm{NH} 4 \mathrm{Oac}, \mathrm{pH} 7.0 \text { extraction } \\
\text { Exchangeable bases }\end{array}$} & \multirow[t]{2}{*}{ BS } & KCl $\mathbf{1}$ & \multirow[t]{2}{*}{$\underset{\mathbf{H}^{+}}{\mathrm{KCl} 1 \mathrm{~N}}$} \\
\hline & $\mathrm{Ca}$ & $\mathrm{Mg}$ & $\mathbf{K}$ & $\mathrm{Na}$ & Total & CEC & & & \\
\hline & \multicolumn{5}{|c|}{$\mathrm{me} / 100 \mathrm{~g}$} & & $\%$ & \multicolumn{2}{|c|}{$\mathrm{me} / 100 \mathrm{~g}$} \\
\hline A- $0 \%$ & 1.39 & 0.43 & 0.07 & 0.08 & 1.97 & 23.99 & 8 & 12.61 & 0.62 \\
\hline B- $5 \%$ & 5.40 & 0.64 & 0.42 & 0.13 & 6.59 & 21.89 & 30 & 7.30 & 0.37 \\
\hline C-10\% & 6.98 & 0.69 & 0.70 & 0.13 & 8.50 & 20.99 & 40 & 3.58 & 0.22 \\
\hline D-15\% & 10.94 & 0.80 & 1.07 & 0.26 & 13.07 & 20.89 & 63 & 0.59 & 0.20 \\
\hline E-20\% & 12.85 & 0.93 & 1.42 & 0.30 & 15.50 & 19.74 & 79 & 0.00 & 0.13 \\
\hline
\end{tabular}

\section{CONCLUSIONS}

Charcoal additions to soil significantly increased height, diameter, and leaf and stem biomass of $A$. mangium and significantly increased height, diameter, number of leaf, root dry weight, stem dry weight, and total biomass of M. montana seedlings in comparison to those of a control. Increasing the amount of charcoal higher than $10 \%$ level, however, have little effect on $A$. mangium growth. Nevertheless, increasing the amount of charcoal higher than $10 \%$ or up to $20 \%$ is still effective on $M$. montana growth. This study indicated that charcoal application at the rate of $10 \%$ for $A$. mangium and $20 \%$ for $M$. montana would be adequate to improve the availability of soil nutrients, and hence significantly induce a better plant growth response.

Charcoal treatment significantly increased soil $\mathrm{pH}$, soil organic $\mathrm{C}$, total $\mathrm{N}, \mathrm{HCl} 25 \%$ extractable $\mathrm{P}, \mathrm{HCl} 25 \%$ and Bray-extractable $\mathrm{K}$, exchangeable bases ( $\mathrm{Ca}, \mathrm{Mg}, \mathrm{Na}$, and $\mathrm{K}$ ), percentage of base saturation, and significantly decreased CEC, and significantly decreased $\mathrm{KCl} 1 \mathrm{~N}$-extractable $\mathrm{Al}^{3+}$ and $\mathrm{H}^{+}$cations.

\section{REFERENCES}

Chidumayo, E. N. 1994. Effects of wood carbonization on soil and initial development of seedlings in miombo woodland, Zambia. Forest Ecology and Management 70: 353 - 357.

Fearnside, P.M. 1991. Green house gas contributions from deforestation in Brazilian Amazonia. In J.S. Levine (Ed.) Global biomass burning. Atmospheric, climatic, and biospheric implications. The MIT Press, Cambridge, Massachusetts, London, England. 92-105. 
Foth, H. D. 1990. Fundamentals of Soil Sciences. John Wiley \& Sons, New York. 435 pp.

Glaser, B., J. Lehmann, and W. Zech. 2002. Ameliorating physical and chemical properties of highly weathered soils in the tropics with charcoal - a Review. Biology and Fertility of Soils 35: 219 - 230.

Holdgate, M. 1995. Greenhouse gas balance in forestry. Forestry 68:297-302.

Ishida, A., T. Toma, S. Mori, and Marjenah. 2000. Effects of foliar nitrogen and water deficit on the carbon economy of Shorea smithiana Sym. seedlings. BIOTROPICA 32: 351 358.

Ishii, T. and K. Kadoya. 1994. Effects of charcoal as a soil conditioner on citrus growth and vesicular-arbuscular mycorrhizal development. Journal of Japan Society for Horticulture Science 63 (3): 529 - 535.

Kishimoto, Y. 1984. Over-look on the other aspect of charcoal industry, Yamasaki Agriculture Research Series No. 3. (in Japanese).

Kishimoto, S. and G. Sugiura 1985. Charcoal as a soil conditioner. Int Archieve Future 5: 1223.

Ogawa, M. 1994. Symbiosis of people and nature in the tropics. Farming Japan 28: 10 - 34. Farming Japan CO., LTD. Tokyo, Japan.

Sanchez, P. A., J. H. Villachia, and D. E. Bandy. 1983. Soil fertility dynamics after clearing tropical rainforest in Peru. Science Society America J 47: 1171 - 1178.

SAS Institute. 1998. SAS User' Guide: Statistics Version, Release 6.12. SAS Ins. Cary, NC.

Siregar, C. A. 2002. Application of mycorrhizal fungi, organic fertilizer and charcoal to improve the growth of indicator plant in tailing soils contaminated with $\mathrm{Pb}$ and Fe in gold mining of PT. Aneka Tambang, Pongkor. Proceedings: Rehabilitation and Forest Conservation. Forest Research and Development Agency. Bogor. (In Indonesian). 